\begin{tabular}{|c|c|c|}
\hline$\exists$ & $\begin{array}{c}\text { International Journal of Current Research } \\
\text { and Academic Review }\end{array}$ & 6. \\
\hline $\begin{array}{l}\text { EXCELLENT } \\
\text { PUBLISHERS } \\
\end{array}$ & 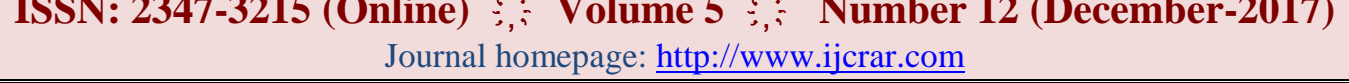 & \\
\hline
\end{tabular}

doi: https://doi.org/10.20546/ijcrar.2017.512.009

\title{
The Impact of Scenario Planning on Marketing Strategy for Private Universities
}

\author{
Khaldiya Mustafa Ata ${ }^{1 *}$, Bushra Shakir Al-Shukri ${ }^{2}$ and Zainab Hayyawi dhair ${ }^{3}$ \\ ${ }^{I}$ College of Administration and Economics, Iraqi University, Iraq \\ ${ }^{2}$ College of Administration and Economics, University of Kufa, Iraq \\ ${ }^{3}$ College of Physical Planning, University of Kufa, Iraq \\ *Corresponding author
}

\begin{abstract}
This research aims to identify the impact of the strategic scenario and its four dimensions (environmental analysis, strategic vision, core competency, teamwork) in the success of marketing strategy for private universities, this study was applied in a sample of universities in central Iraq (Middle Furat), which adopted the questionnaire as a main tool for data collection. The questionnaire was distributed to a sample of (311) respondents, A model for each of the two variables was constructed, and then tested using confirmatory factor analysis, correlation and regression coefficients.
\end{abstract}

\section{Article Info}

Accepted: 30 November 2017

Available Online: 20 December 2017

\section{Keywords}

Scenario planning,

Marketing strategy

\section{Introduction}

In the 19th century, strategists in Germany adopted the first future approach by adopting future scenarios . (Rwibnitz, 1988), this is the first use of the concept of planning scenario.

The first actual use of this concept was in 1960, when the geographic center was established In the United States and France .(Heijden, 2005), And after more than 50 years of development of the concept has become one of the most important ways to deal with the future, where studies and research are still looking at the means of success and constraints(Varum \& Melo, 2010).

The Scenario planners have dealt very well with future discovery situations and scenario-building to reach a specific number of these scenarios. Their main problem was how to reach a specific number of scenarios, so a number of techniques and methods were suggested and introduced. (Kwakkel et al., 2013), Scenario planning is a common tool that is flexible in future preparation and adaptation (Ravera et al., 2011). It provides properties and descriptions rather than predicting a number of possibilities based on multiple perspectives .(Notten et al., 2003)

Scenarios contribute to the discovery of complexities resulting from uncertainty in the future (Wilkinson \& Eidinow, 2008), and when applied, give a future picture of future plans and how they are implemented (Foran et al., 2013), these images are based on a scientific methodology linking quantitative and qualitative elements, which are important in the system's internal coherence process (Foster, 1993) In this context, (Ratcliffe, 2000) points out that good scenarios should represented:

Management tools that contribute to the quality of executive and strategic decisions. Real representation of the future, which contributes to the clarification of current activities from a future perspective. 
This study aims to identify the impact of scenario planning on marketing strategy in private universities.

\section{Literature review}

\section{Scenario planning}

Scenario planning is a process that is formed by developing its components (Focault, 2011), It is a tool that contributes to looking at the future with a broad perspective (Derbyshire \& Wright, 2014), yet, despite this, scenario planning has not yet become a fully developed academic discipline. One reason is argued to be the perception that, despite recent efforts to provide it with a more solid theoretical underpinning, scenario planning remains a practical tool with limited theoretical foundations (Wilkinson, 2009).

\section{Environmental analysis}

The researchers presented multiple views of strategic and environmental analysis. They noted that strategic analysis means a continuous and complex process of leading strategic change, (Delahaye, 2000) which represents an organized effort to make the decisions about the business and strategic directions. (Mintzberg, 1998) In the same context, studies suggest that strategic analysis is a roadmap to the development of the organization's long-term aspirations.

It represents the mechanisms for creating dynamic integration between strategic capabilities and competitive pressures in a coherent process. (Lynch, 2000), This is a core of strategic business thinking and a key tool for exploring the strategic and environmental analysis (Hitt \& Lerland, 2001) is based mainly on (SWOT) analysis within the external environment, which analyzes the competitive environment to diagnose growth opportunities and avoid threats, as well as the internal environment, which is concerned with the analysis of resources and distinctive capabilities (Strength) that support competitiveness, and to avoid weaknesses identified for the construction of a distinctive strategic business (Pearce \& Robbins, 1997).

\section{Strategic vision}

The vision is an ideal and attractive future that has not yet been achieved, it described as a guiding star of every member in organization towards the future (Daft, 2001). It represents a strategic map for the future of the organization that contributes to providing information on future factors such as customers, technology, geographical areas, (Thompson \& Strickland, 2001). The literature suggests that strategic vision is a desirable future situation for organizations, and represents the ambition that makes a strategic leader or executive leader able to focus his concerns toward the goals by encouraging the organization's members to achieve it. (Johnson \& Scholes, 2002).

\section{Core competency}

The concept of core competencies has been prevalent since 1990, which represents the core competencies of organizations as competitive assets that can be assessed and adopted on organizational knowledge through experience. (Thompson \& Tricklond, 1999). The concept was closely associated with the concept of ingenuity in the management of the organization's subsystems, the integration of information technology with processes and the diverse knowledge of the provision of products and services to ensure a competitive advantage. (Macmilan \& Tampo, 2000).

The core competency was defined as representing the distinct business capabilities of the organization so that it distinguishes its products from other competitors' products in order to increase market share (Dessler, 2003).

The core competencies are characterized by many researchers, the most important of which are the small number and greater individual capacity, the basis of the short- and long-term assurance of the organization, the difficulty of imitation and the basis for the strategic intent and strategic options of the organization (Macmilan \& Tampo, 2000).

\section{Team Work}

The team's concept is one of the common concepts of modern administrative literature and has become very important for the success of business organizations. The team represents a unit composed of two or more individuals who have a common message, a collective responsibility and work together to achieve a specific goal (Mescon et al., 2003). They work together to achieve common goals and purpose (Bester field et al., 2003). Team members rely on each other to complete business. They have complementary skills and commitment to goals with ability to take responsibility (Cantu, 2007), they work to achieve efficiency in work (Aslan et al., 2008), which enable them to maximize the 
use of human resources and produce high quality products that contribute to the overall improvement of performance (Henry, 1997).

\section{Marketing Strategy}

Authors and researchers presented multiple concepts of the concept of marketing from multiple perspectives, but the most comprehensive and best concept is presented by Kotler, who defined it as an analysis, organization, planning and customer control of an organization that involves resources, policies and activities designed to meet the needs and desires of customers (Oktay, 2017), Ensuring access to a high market share (Farshid \& Foroughi, 2012), associated with a range of factors that may be unclear to the organization (Fizebakhsh, 2002). The most important of these factors are the external factors that are considered obstacles to the organization for the success of the marketing process such as (economic growth rates, inflation, exchange rate, political stability, price changes, competition, etc.) (Drani et al., 2012).

In this context, organizations have used different strategies to improve their products and services and make them more attractive. This has created a marketing strategy that has become very common and which requires a set of criteria to be used successfully (Guzzo, 2012), Marketing strategy is defined as an interactive process for organizations with competitive market conditions as well as interaction with the environment to achieve the target market objectives (Lee \& Griffith, 2004, Slater et al., 2010). It represents a strategic plan for the organization's goals and how to achieve marketing goals (Walker, 2011), In addition, it represents a future road map for how resources are allocated and linked to environmental factors to achieve the Organization's strategic objectives (Brodrechtovam, 2008), these marketing strategies aim to improve marketing activities and positively change customer behavior and ensure loyalty (Taylor, 2004). This leads to ensuring that they acquire this service or commodity (Chaudhuri \& Holbrook, 2001). the brand is linked marketing strategy (Jandaghi et al., 2011), and marketing strategy will has a vital role in attracting and retaining customers, which contributes to a competitive advantage. Drani et al., 2012)

\section{Materials and Methods}

The study methodology consist of several stages like literatures, data collection $\mathrm{m}$ structural equation modeling and regression analysis, the literature and related studies help to discover the conceptual theory that related to scenario planning and marketing strategy and using the methods of analysis.

And the conceptual model consists from the scenario planning as independent variable and marketing strategy as dependent variable.

\section{Sampling}

The data collection was done by survey in five private universities random sample was selected, 350 questionnaire were distributed 311 were collected (where 29 not received 39 and 10 not vialed). So the details of the sample characteristic shown in table (1).

\section{Normality test}

In order to test the normality of the data that been collected, the study use the normality test using (Amos v. 18 ), the tables (2), (3) shows the result of the normality test all values are between $(-1.96,+1.96)$, so it refers to the following statistical decision: all the data of both variables (Scenario Planning, Marketing Strategy) follow the normal distribution.

\section{Results and Discussion}

\section{Confirmatory factor analysis}

structural equation modeling (SEM) is an appropriate technique for verifying the construction of a high latent construct factors (Pollen, 1989) in order to test the model construction Amos software were used.

And using confirmatory factor analysis (CFA) with (SEM) modeling of structural equations are statistical techniques can use to reduce the number of observed variables of latent variables by examining the variance between them (James et al., 2006: 323)

The adequacy of this tools is is most appropriately applied to measures that are fully developed models, and its validation, and the legitimacy of the application of variables, of course, is linked to the conceptual rationale as a hypothesis test approach to data analysis. This means, based on theory, experimental research, or combination of the two, that the researcher assumes a model and then tests its validity given the sample data (Berne, 2012: 95) all based on appropriate indicators as in Table (4) 


\section{Scenario Planning}

This variable consists of four main dimensions, according to the values of the indicators shown in figure (1), it is appeared that the model were not valid and not good to measure this variable, so it need to modify the model by using (modification indices). As it shown in table (5) and figure (2).

\section{Marketing Strategy}

This variable consists of eight items, according to the values of the indicators shown in figure (3), it is appeared that the model were not valid and not good to measure this variable, so it need to modify the model by using (modification indices), as it shown in table (6) and figure (4).

\section{Hypotheses1}

\section{The relation between scenario planning and marketing strategy}

According to the analysis results that have shown in table (7), the correlation between SP and MS is (0.854) at the sig. with $(0.05)$, and the correlation was significant according to (t- test) that has compared with the $\mathrm{t}$-table value.

The relation between Environmental analysis and marketing strategy

According to the analysis results that have shown in table (7), the correlation between EA and MS is (0.734) at the sig. with $(0.05)$, and the correlation was significant according to (t- test) that has compared with the t-table value.

\section{The relation between Strategic vision and marketing strategy}

According to the analysis results that have shown in table (7), the correlation between SV and MS is (0.714) at the sig. with (0. 05), and the correlation was significant according to (t- test) that has compared with the t-table value.

\section{The relation between Core competency and marketing strategy}

According to the analysis results that have shown in table (7), the correlation between CC and MS is $(0.835)$ at the sig. with (0. 05), and the correlation was significant according to (t- test) that has compared with the t-table value.

\section{The relation between Team Work and marketing strategy}

According to the analysis results that have shown in table (7), the correlation between TW and MS is $(0.495)$ at the sig. with (0. 05), and the correlation was significant according to (t- test) that has compared with the t-table value.

\section{Hypotheses2}

The tradition instrument that has used to test the effect depend on its size, direction, while using SEM it find the plausibility of postulated relations from the (goodness of fit index) (Byrne, 2010: 3).

The table (8) shows the result of effect test, it refers to the effect of scenario planning on marketing strategy, this effect was significant according to the (f-test) value, the independent variable (SP) interpreted (72. 9\%) of the dependent variable (MS), and the regression equation will be as follow $: \mathrm{Y}=0.488+0.841 \mathrm{SP}$

There are significant impact of environmental analysis on marketing strategy, this effect was significant according to the (f-test) value, the independent variable (EA) interpreted (53. 9\%) of the dependent variable (MS), Thus the first sub-hypothesis is supported, and the regression equation will be as follow $: Y=1.577+0.590$ SP.

There are significant impact of Strategic vision on marketing strategy, this effect was significant according to the (f-test) value, the independent variable (SV) interpreted $(51 \%)$ of the dependent variable (MS),

Thus the second sub-hypothesis is supported, and the regression equation will be as follow: $\mathrm{Y}=1.227+0.635$ SV.

There are significant impact of core competency on marketing strategy, this effect was significant according to the (f-test) value, the independent variable (CC) interpreted (24.5\%) of the dependent variable (MS),

Thus the third sub-hypothesis is supported, and the regression equation will be as follow: $\mathrm{Y}=1.923+0.470$ SV. 
Table.1 The sample characteristic for the doctors under study

\begin{tabular}{|c|c|c|c|c|c|}
\hline \multicolumn{6}{|c|}{ Gender } \\
\hline$\%$ & No & $\%$ & No & . & \\
\hline & $\mathrm{M}$ & & $\mathrm{F}$ & & \\
\hline $67.2 \%$ & 209 & $32.8 \%$ & 102 & & \\
\hline \multicolumn{6}{|c|}{ Age } \\
\hline \multicolumn{2}{|c|}{$51-$} & \multicolumn{2}{|c|}{$41-50$} & \multicolumn{2}{|c|}{$31-40$} \\
\hline$\%$ & No. & $\%$ & No. & $\%$ & No. \\
\hline $40.9 \%$ & 127 & $28.6 \%$ & 89 & $30.5 \%$ & 95 \\
\hline \multicolumn{6}{|c|}{ Work experience } \\
\hline \multicolumn{2}{|c|}{$11-$} & \multicolumn{2}{|c|}{ 6-10 years } & \multicolumn{2}{|c|}{$1-5$ years } \\
\hline$\%$ & No. & $\%$ & No. & $\%$ & No. \\
\hline $31.5 \%$ & 98 & $14.2 \%$ & 44 & $54.3 \%$ & 169 \\
\hline
\end{tabular}

Table.2 Normality test for SP data

\begin{tabular}{|c|c|c|c|c|c|c|}
\hline Variable & $\min$ & $\max$ & skew & c. r. & kurtosis & c. r. \\
\hline $\mathrm{q} 10$ & 1.000 & 5.000 & -.917 & -6.599 & .920 & 3.313 \\
\hline $\mathrm{q} 9$ & 1.000 & 5.000 & -1.049 & -7.551 & 1.166 & 4.197 \\
\hline $\mathrm{q} 8$ & 1.000 & 5.000 & -.364 & -2.622 & -.597 & -2.148 \\
\hline $\mathrm{q} 7$ & 1.000 & 5.000 & -.946 & -6.810 & .386 & 1.389 \\
\hline $\mathrm{q} 6$ & 1.000 & 5.000 & -1.052 & -7.576 & .879 & 3.164 \\
\hline $\mathrm{q} 5$ & 1.000 & 5.000 & -.631 & -4.546 & -.059 & -.214 \\
\hline $\mathrm{q} 4$ & 1.000 & 5.000 & -.279 & -2.006 & -.821 & -2.956 \\
\hline $\mathrm{q} 3$ & 1.000 & 5.000 & -.993 & -7.150 & .887 & 3.193 \\
\hline $\mathrm{q} 2$ & 1.000 & 5.000 & -.834 & -6.005 & .980 & 3.527 \\
\hline $\mathrm{q} 1$ & 1.000 & 5.000 & -.753 & -5.424 & .081 & .290 \\
\hline Multivariate & & & & & 41.906 & 23.852 \\
\hline
\end{tabular}

Table.3 Normality test for MS data

\begin{tabular}{|c|c|c|c|c|c|c|}
\hline Variable & $\min$ & $\max$ & skew & c. r. & kurtosis & c. r. \\
\hline Y8 & 1.000 & 5.000 & -1.094 & -7.875 & .830 & 2.988 \\
\hline Y7 & 1.000 & 5.000 & -.589 & -4.241 & .313 & 1.128 \\
\hline Y6 & 1.000 & 5.000 & -.399 & -2.874 & -.407 & -1.466 \\
\hline Y5 & 1.000 & 5.000 & -.323 & -2.327 & -.135 & -.487 \\
\hline Y4 & 1.000 & 5.000 & -.757 & -5.448 & .961 & 3.461 \\
\hline Y3 & 2.000 & 5.000 & -.423 & -3.044 & -.555 & -1.997 \\
\hline Y2 & 1.000 & 5.000 & -.524 & -3.775 & -.236 & -.848 \\
\hline Y1 & 1.000 & 5.000 & -1.096 & -7.894 & 1.167 & 4.202 \\
\hline Multivariate & & & & & 26.668 & 18.590 \\
\hline
\end{tabular}


Table.4 Fit indices for modeling

\begin{tabular}{|c|c|c|}
\hline Fit Index & $\begin{array}{c}\text { Acceptable } \\
\text { Threshold Levels }\end{array}$ & Description \\
\hline $\begin{array}{l}\text { Absolute Fit } \\
\text { Indices Chi- } \\
\text { Square X2 }\end{array}$ & $\begin{array}{c}\text { Low } X 2 \text { relative to } \\
\text { degrees of freedom } \\
\text { with an insignificant } \\
p \text { value }(p>0.05)\end{array}$ & \\
\hline $\begin{array}{l}\text { Relative } x^{2} \\
\left(x^{2} / \mathrm{df}\right)\end{array}$ & $\begin{array}{l}2: 1 \text { (Tabachnik \& } \\
\text { Fidell, 2007) } \\
3: 1 \text { (Kline, 2005) } \\
\end{array}$ & Adjusts for sample size. \\
\hline (RMSEA) & $\begin{array}{l}\text { Values less than } \\
0.07 \text { (Steiger, 2007) }\end{array}$ & $\begin{array}{l}\text { Has a known distribution. Favours parsimony. } \\
\text { Values less than } 0.03 \text { represent excellent fit. }\end{array}$ \\
\hline GFI & $\begin{array}{l}\text { Values greater than } \\
0.95\end{array}$ & $\begin{array}{c}\text { Scaled between } 0 \text { and } 1 \text {, with higher values } \\
\text { indicating better model fit. This statistic should be } \\
\text { used with caution. }\end{array}$ \\
\hline AGFI & $\begin{array}{l}\text { Values greater than } \\
0.95\end{array}$ & $\begin{array}{c}\text { Adjusts the GFI based on the number of } \\
\text { parameters in the model. Values can fall outside } \\
\text { the } 0-1.0 \text { range. }\end{array}$ \\
\hline RMR & $\begin{array}{l}\text { Good models have } \\
\text { small RMR } \\
\text { (Tabachnik and } \\
\text { Fidell, 2007) } \\
\end{array}$ & $\begin{array}{c}\text { Residual based. The average squared } \\
\text { differences between the residuals of the sample } \\
\text { covariance and the residuals of the estimated } \\
\text { covariance. }\end{array}$ \\
\hline SRMR & $\begin{array}{c}\text { SRMR less } 0.08 \\
\text { (Hu\& Bentler, 1999) }\end{array}$ & $\begin{array}{l}\text { Standardized version of the RMR. Easier to } \\
\text { interpret due to its Standardized nature. }\end{array}$ \\
\hline \multicolumn{3}{|c|}{ Incremental Fit Indices } \\
\hline $\mathrm{NFI}$ & $\begin{array}{l}\text { Values greater than } \\
0.95\end{array}$ & $\begin{array}{l}\text { Assesses fit relative to a baseline model which } \\
\text { assumes no covariance between the observed } \\
\text { variables. Has a tendency to fit in small samples. }\end{array}$ \\
\hline NNFI (TLI) & $\begin{array}{l}\text { Values greater than } \\
0.95\end{array}$ & $\begin{array}{l}\text { Non-normed, values can fall outside the } 0-1 \\
\text { range. Favours parsimony. } \\
\text { Performs well in simulation studies (Sharma et al, } \\
\text { 2005; McDonald and Marsh, 1990) }\end{array}$ \\
\hline $\mathrm{CFI}$ & Values greater 0.95 & Normed, 0-1 range. \\
\hline
\end{tabular}

Source: Daire H., Joseph C., Michael R. Mullen, Structural Equation Modeling: Guidelines for Determining Model Fit, Journal of Business Research Methods Volume 6 Issue 1 2008: p58.

Table.5 Indicators for modified model for SP

\begin{tabular}{|c|c|c|}
\hline Indicator & Value & Condition \\
\hline Chi/DF & 4.677 & support \\
\hline GFI & 0.971 & support \\
\hline AGFI & 0.904 & support \\
\hline RMSEA & 0.077 & support \\
\hline CFI & 0.954 & support \\
\hline
\end{tabular}

Table.6 Indicators for modified model for MS

\begin{tabular}{|c|c|c|}
\hline Indicator & Value & Condition \\
\hline Chi/DF & 2.518 & support \\
\hline GFI & 0.985 & support \\
\hline AGFI & 0.921 & support \\
\hline RMSEA & 0.077 & support \\
\hline CFI & 0.986 & support \\
\hline
\end{tabular}


Table.7 Correlation coefficient results

\begin{tabular}{|c|c|c|c|c|c|}
\hline IV & $\mathbf{r}$ & $\bar{T}$ & Sig. & DV & Hypotheses \\
\hline EA & 0.734 & 19.022 & 0.000 & \multirow{5}{*}{$\begin{array}{c}\text { Marketing } \\
\text { Strategy }\end{array}$} & supported \\
\hline SV & 0.714 & 17.918 & 0.000 & & supported \\
\hline $\mathrm{CC}$ & 0.835 & 10.015 & 0.006 & & supported \\
\hline TW & 0.495 & 26.685 & 0.000 & & supported \\
\hline SP & 0.854 & 28.797 & 0.000 & & supported \\
\hline
\end{tabular}

Table.8 Simple regression results

\begin{tabular}{|c|c|c|c|c|c|c|c|}
\hline IV & a & $\overline{\mathrm{B}}$ & $\mathbf{F}$ & $\mathbf{R}^{2}$ & Sig. & DV & Hypotheses \\
\hline EA & 1.577 & 0.590 & 361.85 & 0.539 & 0.000 & \multirow{4}{*}{$\begin{array}{c}\text { Marketing } \\
\text { Strategy }\end{array}$} & supported \\
\hline SV & 1.227 & 0.635 & 321.072 & 0.510 & 0.000 & & supported \\
\hline $\mathrm{CC}$ & 1.923 & 0.470 & 100.30 & 0.245 & 0.006 & & supported \\
\hline TW & 0.641 & 0.792 & 712.08 & 0.697 & 0.000 & & supported \\
\hline
\end{tabular}

Table.9 Multiple regression results

\begin{tabular}{|c|c|c|c|c|c|c|c|}
\hline IV & a & B & $\bar{T}$ & $\overline{\mathbf{R}^{2}}$ & $\mathbf{F}$ & Sig. & Hypotheses \\
\hline EA & \multirow{4}{*}{0.414} & 0.138 & 3.902 & \multirow{4}{*}{0.759} & \multirow{4}{*}{141.56} & 0.000 & supported \\
\hline SV & & 0.202 & 5.669 & & & 0.000 & supported \\
\hline $\mathrm{CC}$ & & -0.054 & -1.498 & & & 0.135 & Not supported \\
\hline TW & & 0.567 & 11.374 & & & 0.000 & supported \\
\hline
\end{tabular}

Fig.1 Proposed model of (SP) according to (SEM)

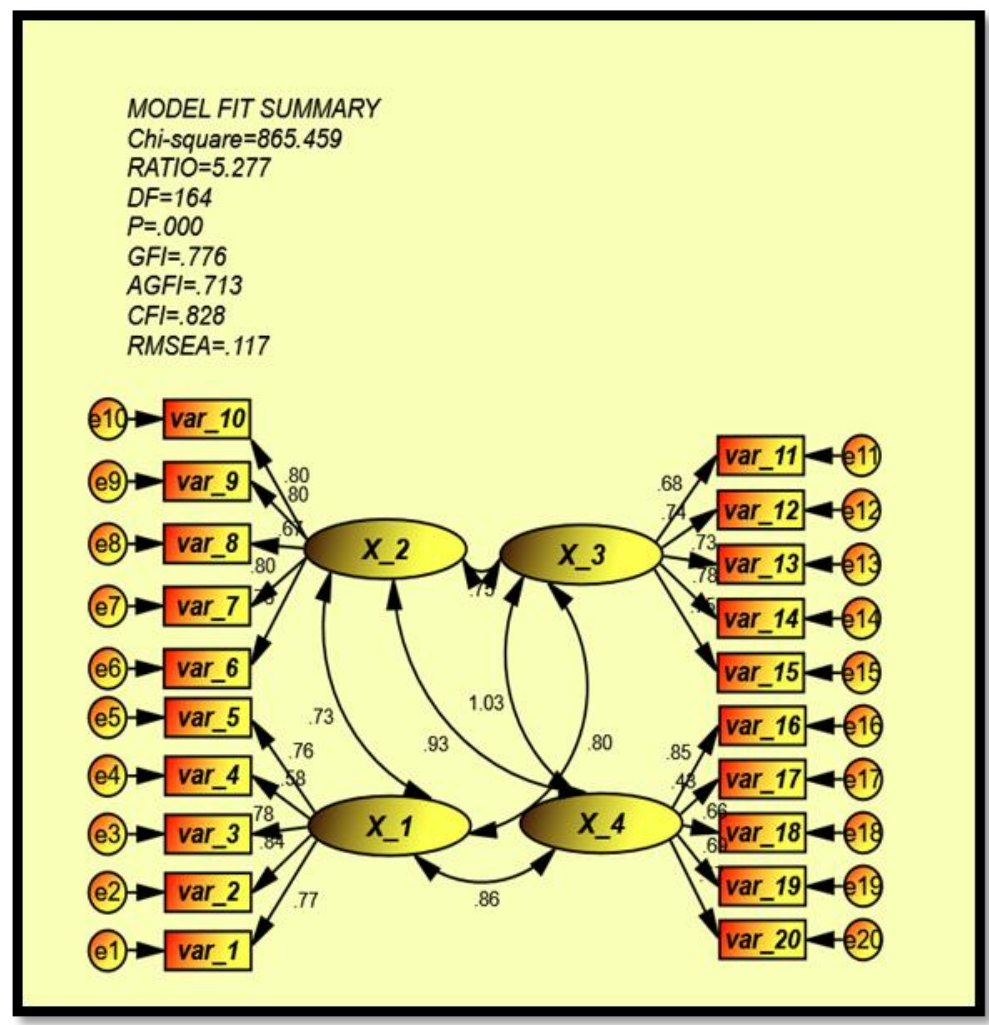


Fig.2 Modified model of (SP) according to (SEM)

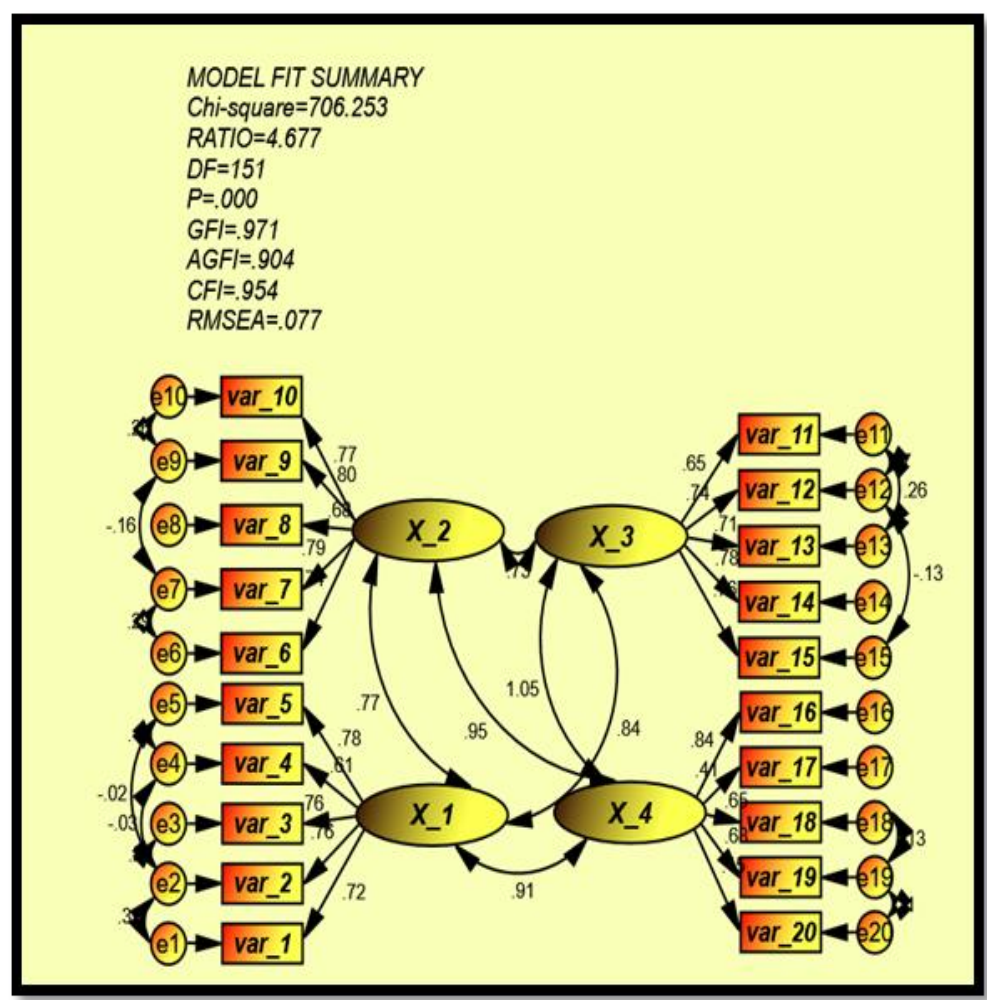

Fig.3 Proposed model of (MS) according to (SEM)

MODEL FIT SUMMARY

Chi-square $=163.662$

RATIO $=8.183$

$D F=20$

$P=.000$

$\mathrm{GFI}=.874$

AGFI $=.773$

$\mathrm{CFI}=.843$

RMSE $A=.152$

var_1 (-1)

var_2

var_3 (e3)

var_4 (e4)

$Y$

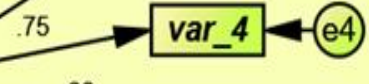

66

var_5 - e5

var_6 -6)

var_7 (e7)

var_8 8 
Fig.4 Modified model of (MS) according to (SEM)

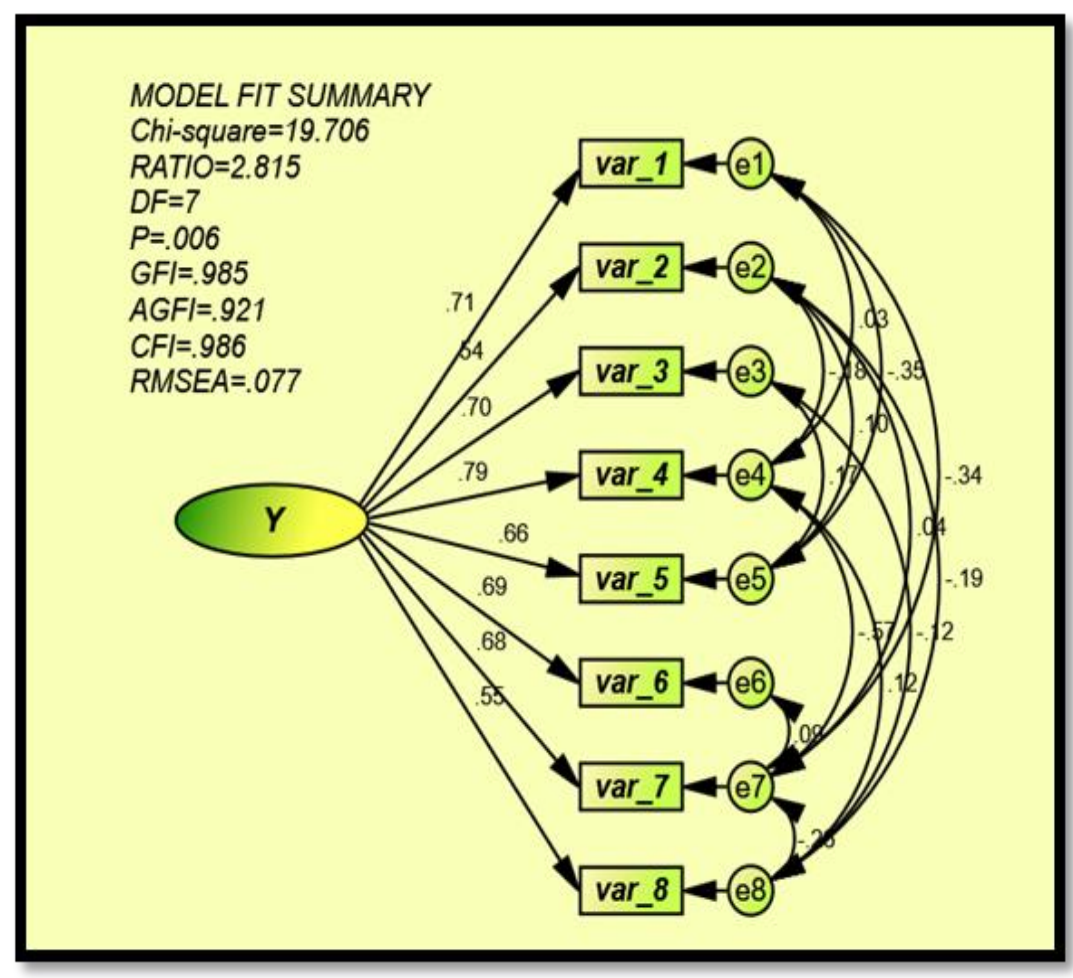

Fig.5 Multiple regression results

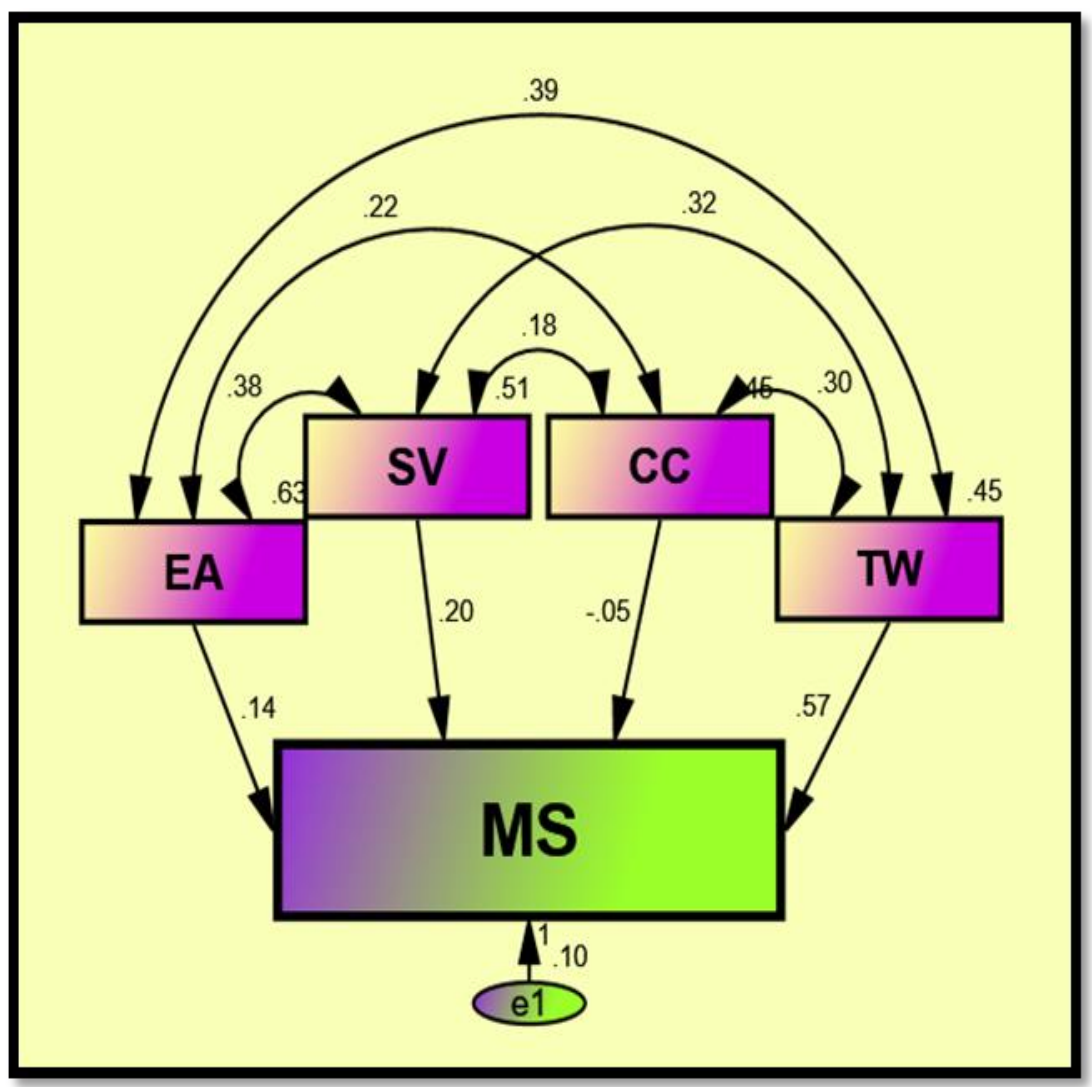


Fig.6 Final model

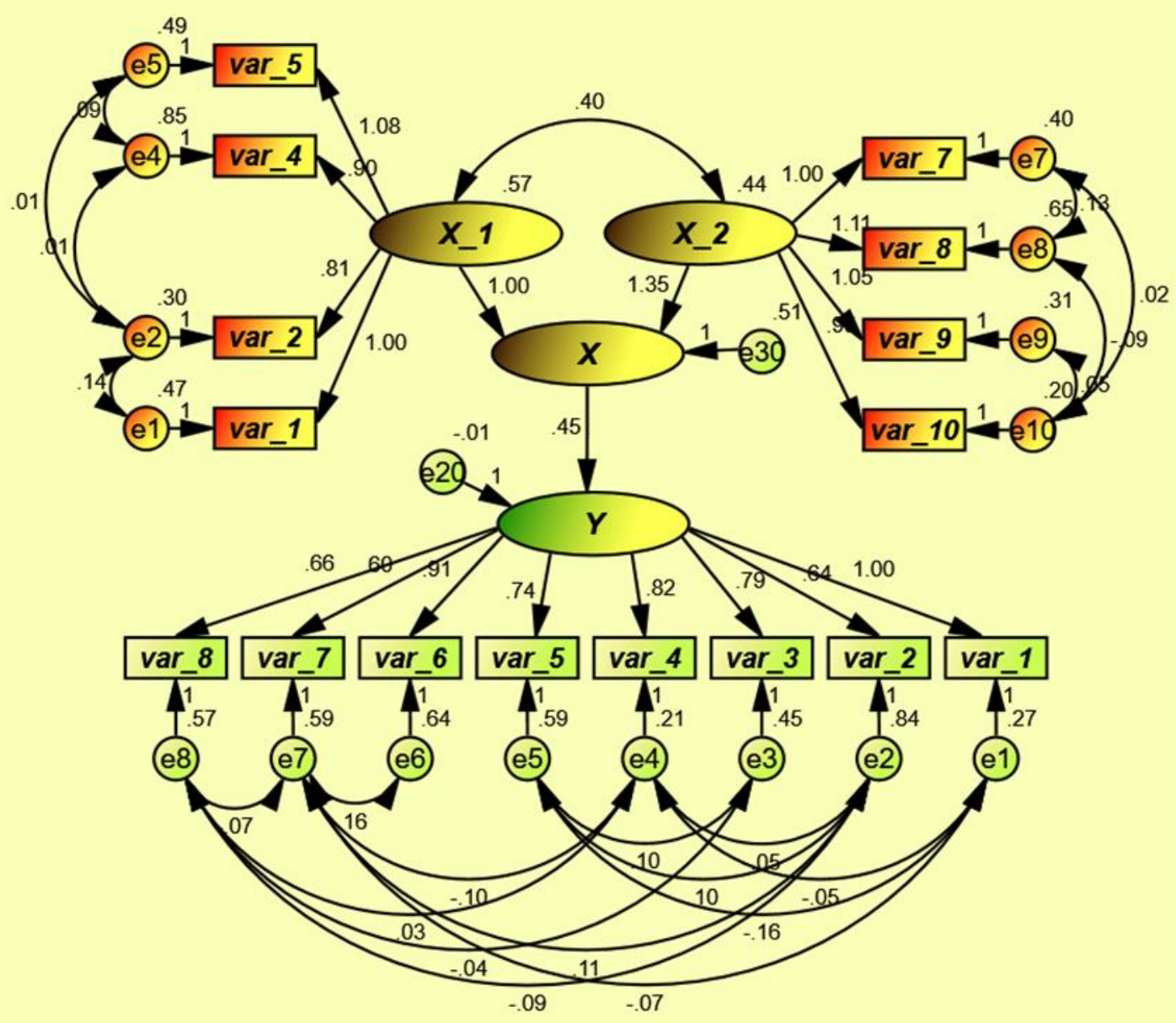

There are significant impact of team work on marketing strategy, this effect was significant according to the (ftest) value, the independent variable (CC) interpreted (24. 5\%) of the dependent variable (MS), Thus, the fourth sub-hypothesis is supported, and the regression equation will be as follow : $\mathrm{Y}=0.641+0.792 \mathrm{SV}$.

With the multiple regression as shown in table (8) and figure (5), there are significant impact for the model of scenario planning on marketing strategy, this effect was significant according to the (f-test) value and (P-value) for three factors (environmental analysis, strategic vision, teamwork), however, it is not significant with one factor (core competency) due to (P-value) that indicate (more than 0. 05), the model interpreted $(75.9 \%)$ of the variation of marketing strategy.

The final model in figure (6) refers to the direct effect of the scenario planning as independent variable on the marketing strategy as dependent variable with value $(0$. 45), which takes into consideration all factors and their items.

Survival and growth in an uncertain and rapidly changing environment with many possibilities in the future is largely reflected in how the future marketing strategy is defined.

In recent years, the private universities concerned with the shift from production orientation to marketing orientation in order to be able to face competition in higher education. The Iraqi Ministry of Higher Education has started granting licenses to establish private universities on high conditions in order to encourage them to reduce their performance. Private universities are trying to find out the successful methods to build a strategy to ensure that their services are successfully marketed, this requires organizations to identify their 
chances of success and look for the factors needed to prepare for the future. Scenario planning has emerged as one of the important factors that can contribute to the success of the marketing strategy.

Despite some of the difficulties that this study faced when collecting data from private universities that are linked to the future marketing plans, the study found that it is very important to adopt the scenario planning in building the university marketing strategy.

In this situation it became clear that scenario planning factors contribute to the formation of marketing strategy, which leads to the marketing strategy to be effective and successful. It has become clear that understanding the environmental factors and conducting strategic environmental analysis of a clear strategic vision with the availability of the core competency and team work capabilities, are important requirements for building strategic scenarios that achieve more effective marketing strategy.

\section{Limitations}

This study has a limitations, The study has been carried out in a sample of private universities within the central region of Iraq (Middle Furat), therefore cannot be generalized to all private universities in the country. So, future studies should try to expand the sample to include a larger number of private universities throughout the country

\section{References}

Amini, A., Darani, M., Afshani, M., \& Amini, Z. 2012. Effectiveness of marketing strategies and corporate image on brand equity as a sustainable competitive advantage. Interdisciplinary Journal of Contemporary Research in Business, 4(2), 192-205.

Arthur A. Thompson, Alonzo J. Strickland, 2001. "Strategic Management: Concepts and Cases", 12th. Ed., McGrawhill/Irwin. S. A.

Aslan, S., Ozan, M., \& Mete, M., 2008. The investment of effect of group emotional Intelligence on team effectiveness, Humanity and Social Sciences Journal $3(2)$.

Bester field, D., bester field - Michana, C., bester field, G., \& bester field - Sachke, M., 2003. Total quality management, 3rd, Person Prentice Hall, New Jersey.

Brodrechtova, Y. 2008. Determinants of export marketing strategies of forest products companies in the context of transition-The case of Slovakia. Forest Policy and Economics, 10(7), 450-459.

Cantu, C., J., 2007. Evaluating team effectiveness: Examination of the team assessment tool, Dissertation for doctoral, University of North Texas

Chaudhuri, A., \& Holbrook, M. B. 2001. The chain of effects from brand trust and brand affect to brand performance the role of brand loyalty. Journal of Marketing, 65(2), 81-93.

Daft L. Richard, Raymond, A. Noe, 2001. "Organization Behavior", Harcourt Co. College Publishers.

Delahaye, B. L. 2000. "Strategic Human Resource Development" Milton John wile \& sons.

Derbyshire, J., Wright, G., 2014. Preparing for the future: development of an 'ant fragile' methodology that complements scenario planning by omitting causation. Technol. Forecast. Soc. Chang. 82, 215225.

Dessler, G. 2003. Human Resource Management, 9th edn. Englewood Cliffs, NJ: Prentice Hall.

Fizebakhsh, A. H. 2002. Investigation of effective factors on increase export of Iran Petrochemical Commercial Company (IPCC) products. Tehran University.

Foran, T., Ward, J., Kemp-Benedict, E. J., Smajgl, A., 2013. Developing detailed foresight narratives: a participatory technique from the Mekong region. Ecol Soc. 18 (4), 6. http://dx. doi. org/10. 5751/ES05796-180406.

Foucault, M., 2011. The Courage of the Truth (the Government of Self and Others II): Lectures at the College de France, 1983-1984. Palgrave Macmillan, Basingstoke.

Guzzo, T., D'Andrea, A., Ferri, F., Grifoni, P. 2012. Evolution of Marketing Strategies. From Internet Marketing to M-Marketing, Springer Verlag Berlin Heidelberg, pp. 627-636.

Henrey, L., J., 1997. The effect of group process training on team effectiveness, dissertation for doctoral, college of health sciences, Texas Women's University.

Hitt M. \& Lreland R. 2001. "Strategic management, competitiveness and globalization 4thed, South College pub.

Jandaghi, G., Amini, A., Pirani, P., Amini, Z., Kharazi, H. 2011 . Survey the Role of Brand in Formation of Customer Loyalty in Financial Services Marketing by the Approach of Small Firms (Case Study of Iran Melli Bank).

Johnson Gerry, Scholes Kevan, 2002. "Exploring Corporate Strategy: Text and Cases", 6th. ed. Financial Times, Prentice Hall, New York. 
Kwakkel, J. H., Auping, W. L., Pruyt, E., 2013. Dynamic scenario discovery under deep uncertainty: the future of copper. Technol. Forecast. Soc. Chang. 80, 789-800. NATO, 2003. Handbook on Long Term Defence Planning. (doi: RTO-TR-069 AC/323(SAS-025)TP/41).

Lee, C., \& Griffith, D. A. 2004. The marketing strategy performance relationship in an export-driven developing economy: A Korean illustration. International Marketing Review, 21(3), 321-334.

Lynch R. 2000. "Corporate Strategy" 2nd ed, Prentice Hall INC.

M. J. Foster, Scenario Planning for Small Business. Long Range Planning 1993, Vol. 26, No. 1, pp. $32-46$.

Macmillan, Hugh., \& Tampo, Mahen., 2000. "Strategic management: Process, Content, And Implementation", Oxford university press, USA.

Mescon, M., H., Bovee, C., L., \& Thill, J., V., 2003. Business today, 10 th ed, prentice Hall, New Jersey

Mintzberg, H. 1998. "The Strategic Process" Revised European Edition, Prentico-Hall INC.

Notten, P. W. F., Rotmans, J., van Asselt, M. B. A., Rothman, D. S., 2003. An updated scenario typology. Futures 35, 423-443.

Oktay, S. 2017. An analytical study to identify and determine the usage frequency of sales and marketing strategies for 5 star hotels in the Antalya region. Procedia Computer Science, 120, 862-870.

Pearce J. A. \& Robbins S. K. 1997. "The Impact of Grand Strategy on Financial Performance" Strategic Management Journal Vol. 12.

Ratcliffe, J., 2000. Scenario building: a suitable method for strategic property planning. Property Management. 2000, Vol. 18, No. 2, pp. 127-44.

Ravera, F., Tarrasó n, D., Simelton, E., 2011. Envisioning adaptive strategies to change:

\section{How to cite this article:}

Khaldiya Mustafa Ata, Bushra Shakir Al-Shukri and Zainab Hayyawi dhair. 2017. The Impact of Scenario Planning on Marketing Strategy for Private Universities. Int.J.Curr.Res.Aca.Rev. 5(12), 65-76.

doi: https://doi.org/10.20546/ijcrar.2017.512.009 participatory scenarios for agropastoral semiarid systems in Nicaragua. Ecol. Soc. 16, 20, http://www. Ecology and society. org/vol16/iss1/art20>.

Reibnitz, U. V. 1988. Scenario techniques. Hamburg, Germany: McGraw-Hill.

Slater, S. F., Hult, G. T. M., \& Olson, E. M. 2010. Factors influencing the relative importance of marketing strategy creativity and marketing strategy implementation effectiveness. Industrial Marketing Management, 39(4), 551-559.

Taylor, S. A., Celuch, K., \& Goodwin, S. 2004. The importance of brand equity to customer loyalty. Journal of Product \& Brand Management, 13(4), 217-227.

Tompson, A., \& Strickland, A., 1999. "Strategic Management Concept and Cases", 11th ed, Irwin Mc Graw-Hill, Boston.

Van der Heijden, K. 2005. Scenarios: The art of strategic conversation (2nd ed.). Chichester, UK, Hoboken, NJ: Wiley (xxiv, 356).

Varum, C. A., \& Melo, C. 2010. Directions in scenario planning literature-A review of the past decades. Futures, 42(4), 355-369. http://dx. doi. org/10. $1016 /$ j. futures. 2009. 11. 021

Walker, O. 2011. Outlines \& Highlights for Marketing Strategy: A Decision Focused Approach by: Cram101. Weiss, D. L. 1968. Determinants of market share. Journal of Marketing Research, 290295.

Wilkinson, A., 2009. Scenarios practices: in search of theory. J. Futur. Stud. 13, 107-114.

Wilkinson, A., Eidinow, E., 2008. Evolving practices in environmental scenarios: a new scenario typology. In: Environmental Research Letters 3, 045017. Online at: <stacks. iop. org/ERL/3/045017>. 